\title{
NELFCD wt Allele
}

National Cancer Institute

\section{Source}

National Cancer Institute. NELFCD wt Allele. NCI Thesaurus. Code C105098.

Human NELFCD wild-type allele is located in the vicinity of $20 q 13$ and is approximately 14 $\mathrm{kb}$ in length. This allele, which encodes negative elongation factor C/D protein, plays a role in the inhibition of transcriptional elong ation. 